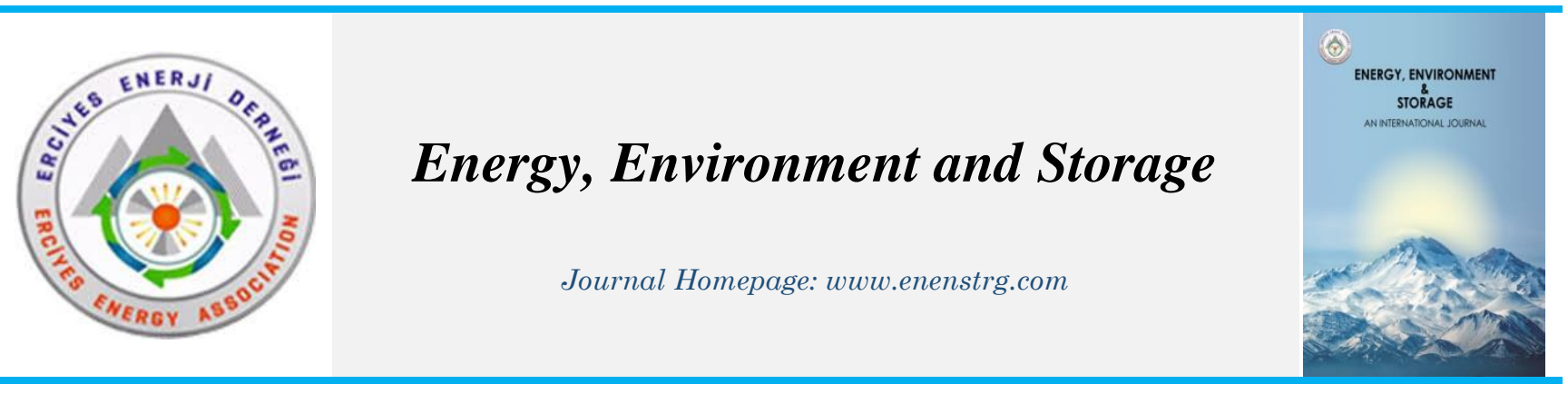

\title{
Evaluation of Carbon Footprint in a Waste Recovery/Recycle Facility
}

\author{
Furkan Demirbas ${ }^{1}$, Nuray Ates ${ }^{2^{*}}$ \\ ${ }^{1}$ State Hydraulic Works, Sivas, Turkey \\ $2^{*}$ Erciyes University, Environmental Engineering Department, Kayseri, Turkey
}

\begin{abstract}
The greatest danger for a healthy world is releasing greenhouse gases into the environment as a result of the industrialization activities in all countries. These released gases play an important role in damaging the health of human beings as well as of destroying nature. In addition to sustainable development practices in order to reduce emissions, it is also necessary to implement clean environment rules. In this study, the carbon footprint of a Waste Recovery/Recycle Facility within the borders of Kayseri Province as results of its operations was evaluated. Correspondingly, the amount of carbon footprint of transportation of waste collection, heating, and electricity usage in the plant site during operations has been examined. Tier 1 and Tier 2 methodologies developed by the Intergovernmental Panel on Climate Change (IPCC) were used to determine the carbon footprint of the facility. As a result, transportation activity due to waste collection contributes to the highest share of carbon footprint with $76.8 \%$. The carbon footprint, which is caused by consumption of natural gas for heating with $23.1 \%$, follows the transportation. Electricity usage has a share of less than $0.1 \%$. The total $\mathrm{CO}_{2}$ emission of the plant was 132711 tons, while the $\mathrm{CO}_{2}$ emission amounts of transportation, heating and electricity use were found to be 102000 tons, 30700 tons and 11 tons, respectively.
\end{abstract}

Keywords: Greenhouse gases, sustainable development, waste recovery, $\mathrm{CO}_{2}$ emission, carbon footprint.

Article History: Received:11.10.2020; Revised: 5.4.2021; Accepted:5.5.2021; Available online: 28.04.2021

Doi: https://doi.org/10.52924/YANA8929

\section{INTRODUCTION}

The international policy community is highly concerned with anthropogenic $\mathrm{CO}_{2}$ emissions, as it is believed to trigger global warming and its consequences can adversely affect global welfare. The largest share (58.6\%) contributing to greenhouse gases is $\mathrm{CO}_{2}$ emissions released from the burning of fossil fuels. Other contributing gases are total collective $\mathrm{CH} 4$ and $\mathrm{N} 2 \mathrm{O}$, respectively $14.3 \%$ and $7.9 \%$ in terms of $\mathrm{CO} 2$ equivalent [1].

With the scientific evidence obtained within the scope of the World Meteorology Organization (WMO) Global Climate Research and Monitoring Project, it was stated that human activities damaged the global climate balance in the first half of the 1970s, and the First World Climate Conference was held in 1979 under the leadership of WMO $[2,3]$. In this conference, where the first serious step was taken in order to protect the global climate system, the importance of the issue was brought to the attention of the world countries for the first time [4]. In the "Changing Atmosphere Conference" held in Toronto, Canada in 1988, the IPCC was established with the joint initiative of the United Nations Environment Program and the World

\section{*Corresponding author: nuraya@erciyes.edu.tr}

Meteorological Organization [5]. The Panel, established to assess the risks of climate change caused by human activities, is an international organization [6]. The first and most important step taken in the international arena was the United Nations Framework Convention on Climate Change (UNFCCC), which was opened for signature at the United Nations (UN) Environment and Development Conference held in Rio de Janeiro in 1992. It entered into force in 1994 $[7,8]$. In this agreement, Turkey has been involved in both Annex I that requires historical responsibility and Annex II that requires financial responsibility [9]. As the UNFCCC could not determine a work program based on precise data to reduce carbon footprint and could not cooperate between countries to reduce greenhouse gas emissions, different regulations are required to reduce greenhouse gas emissions in the fight against global warming. At the $3^{\text {rd }}$ Conference of the Parties held in 1997 in Kyoto, Japan, the Kyoto Protocol, which is a recommendation and has a binding feature to cover the gaps in the UNFCCC, was established and entered into force in 2005 [10,11]. In this conference, many countries supported the reduction of greenhouse gas emissions by $15 \%$ of the 1990 level until 2010 [11]. The agreement, to which 196 countries are parties, has reached a wide participation and has the highest number of 
participants among international environmental agreements [4].

The atmospheric greenhouse gas stock needs to be stabilized below $550 \mathrm{ppm}$ in carbon dioxide equivalent to provide the $2^{\circ} \mathrm{C}$ target $[1,12]$. Therefore, all countries are making efforts towards sustainable production in order to determine their greenhouse gas inventories and reduce $\mathrm{CO}_{2}$ emissions all over the world. With the Kyoto Protocol, climate change issues occupy an important place in the political and institutional agenda of the countries and the countries that signed the protocol have accepted their responsibility to take action against global warming [13].

The term of carbon footprint was derived from the concept of ecological footprint and can be defined as measure of the total amount of $\mathrm{CO}_{2}$ emission caused by a direct or indirect activity or by a product at each stage of its life in nature is defined as the carbon footprint [14-16]. The direct carbon footprint refers to carbon dioxide emissions from the combustion of fuels including consumed for heating and transportation purposes. Indirect carbon footprint covers carbon dioxide emissions caused by the entire life cycle of a product from the raw material used in its production to its final disposal [17]. Besides, the carbon footprint is conceptually used as an indicator of global warming potential [12,16-20]. The carbon footprint is usually computed for a specific time period such as 100 years and is expressed in units of mass of carbon dioxide equivalents per unit time or per unit product (i.e. $\mathrm{kg} \mathrm{CO}_{2}$ equivalent) $[12,16,21]$. In estimating the carbon footprint, data of the activity is multiplied by standard emission factors [22]. According to the Kyoto protocol, the total $\mathrm{CO}_{2}$ equivalent of six greenhouse gases, which are methane, nitrous oxide, hydrofluorocarbons, perfluorocarbons and sulfur hexafluoride, are taken into account in addition to $\mathrm{CO}_{2}$ emission [23].

The studies on climate change revealed that most of the carbon footprint that causes climate change in cities occurs in regions where transportation is intense. Especially in cities, $\mathrm{CO}_{2}$ emissions are increasing due to the high use of personal vehicles, density of fossil fuel use and being commercial focus centers. Mehrotra et al. [24] reports that $75 \%$ of the carbon footprint is formed in cities and $95 \%$ of fossil fuels are consumed in cities. According to the data of the International Energy Agency (IEA), the transportation sector is the sector that produces the highest amount of carbon footprint after the electricity and heat generation sectors, and more than $70 \%$ of this footprint is due to road transport [4,25].

In this study, the carbon footprint for a waste recovery facility was estimated. The facility is located in Incesu within the boundaries of Kayseri District. In the facility, the wastes including plastic drums, Intermediate Bulk Containers (IBC) and sheet metal barrels were separated, sorted, cleaned and then recovered. In the scope of the study, the carbon footprint estimation was performed in three categories consisting of transportation, heating, and electricity consumption due to facility activities. The Tier approach in the IPCC manual was used [26].

\section{MATERIALS AND METHODS}

\subsection{Description of Waste Recovery Facility}

In this study, carbon footprint estimation was investigated in a waste recovery facility in 2018 . The facility operates as a hazardous waste recovery located within the borders of Incesu district of Kayseri Province. The facility is built on a $1200 \mathrm{~m}^{2}$ closed area and consists of administrative building, contaminated packaging areas, washing area, wastewater treatment plant, clean packaging field, press area, non-hazardous waste field and transformer center. At the facility, 6 workers work for 8 hours, one shift per day. Waste is collected from waste producers operating in Kayseri Organized Industrial Zone and neighboring provinces (Gaziantep and Yozgat), 2 times a day with 3 separate waste transportation vehicles to the facility. Waste comes from Gaziantep at a distance of $330 \mathrm{~km}$ and Yozgat at a distance of $160 \mathrm{~km}$ once a month to the waste recycling facility. The types of waste brought to the recycling facility include plastic drums, IBC tanks and sheet metal barrels. The facility has potential to recycle 1200 tons of Intermediate Bulk Container (IBC) and 1800 tons of barrels per year. Hazardous wastes separated according to their types are kept in the contaminated waste storage area prepared separately for each of them to be taken to the washing unit. Each waste received into the washing unit is treated separately according to the chemical substance it is exposed to. Pressurized water and solvent are used in the washing unit. Sheet metal barrels and plastic drums are washed by adding hot water and chemicals using a gun. The wastes that cannot be recovered are passed through the washing unit and then pressed to the iron and steel rolling mill facilities. In addition, small-sized wastes contaminated with hazardous chemicals brought to the facility are separated according to their types and stored on an impermeable concrete floor. The waste material, which is passed through the crushing machine, is taken into the washing baskets and passed through the washing process. Cleaned crushed small materials are pressed and sent as metal raw materials. Crushed and cleaned small plastic parts are stored in sacks and sent to the plastic industry as raw material. The wastewater generated in the washing unit is treated in the treatment plant.

\subsection{The Methodology of Carbon Footprint Estimation}

In the facility, the carbon footprint estimation was performed in three categories: transportation, heating, and electricity consumption. The 2006 IPCC Manual uses three methodologies for estimating fossil fuel emissions. In these approaches called Tier 1, Tier 2, and Tier 3, as the Tier level increases, the number of data and details used increase [26]. Generally, Tier 1 Tier 2 methods are used for $\mathrm{CO}_{2}$ emission caused by natural gas and electricity consumption, respectively. In the Tier 3 method, facility-specific fuel consumption and emission factors are used, so it is considered to be a realistic calculation. The difference between Tier 2 and Tier 3 methods from Tier 1 method is the use of fuel consumption and distribution values. In the Tier 2 method, carbon footprint calculation is made by dividing fuel consumption into groups and selecting the appropriate emission factor. In the Tier 3 method, detailed procedures such as the length of the road traveled by the vehicles, the ratio of the weight of the carried weight to the 
length of the road traveled are included in the carbon footprint calculation and selecting the appropriate emission factor [26].

The Tier 1 method is a simple method with limited data. This method, which is generally used for the transportation sector, is based on the burning of fuels. The principle of this method, which is widely used in $\mathrm{CO}_{2}$ calculation and also called top-down, is the estimation of the carbon footprint in proportion to the fuel burned. Firstly, the amount of fuel consumption in the facility is determined and it is multiplied by conversion factor to calculate the energy content of the fuel (Eq. 1). Secondly, carbon content of fuel is computed by using energy content and appropriate carbon emission factor (Eq. 1). Thirdly, carbon emission is calculated from the amount of carbon exposed to combustion by using the oxidation factor of the fuel based on the fuel type, (Eq. 3). Finally, the carbon footprint calculation is completed by converting the carbon emission into $\mathrm{CO}_{2}$ (Eq. 4). Table 1 shows net calorific values and carbon emission factors of fuels.

$$
\begin{aligned}
& \mathrm{EC}[\mathrm{tJ}]=\mathrm{FC}[\mathrm{t}] * 10^{-3} * \mathrm{CF}[\mathrm{tJ} / \mathrm{kt}] \\
& \mathrm{CC}[\mathrm{Gg} \mathrm{C}]=\mathrm{CEF}[\mathrm{tC} / \mathrm{tJ}] * \mathrm{EC}[\mathrm{tJ}] \\
& \mathrm{CE}[\mathrm{Gg} \mathrm{C}]=\mathrm{CC}[\mathrm{Gg} \mathrm{C}] * \mathrm{COF}
\end{aligned}
$$

$$
\mathrm{CO}_{2} \text { Emission }\left[\mathrm{Gg} \mathrm{CO} \mathrm{CO}_{2}\right]=\mathrm{CE} * \frac{\mathbf{4 4}}{\mathbf{1 2}}
$$

Where, EC is energy content, FC is fuel consumption, CF is conversion factor, $\mathrm{CC}$ is carbon content, $\mathrm{CEF}$ is carbon emission factor, $\mathrm{CE}$ is carbon emission and $\mathrm{COF}$ is carbon oxidation factor.

Table 1. Net Calorific Values and Carbon Emission Factors of Fuels [26]

\begin{tabular}{|l|c|c|}
\hline Fuel Type & $\begin{array}{c}\text { Calorific Value } \\
(\mathbf{t J} / \mathbf{k t})\end{array}$ & $\begin{array}{c}\text { Carbon Emission } \\
\text { Factor }(\mathbf{t C} / \mathbf{t J})\end{array}$ \\
\hline Gasoline & 44.8 & 18.9 \\
\hline Diesel & 43.3 & 20.2 \\
\hline LPG & 47.3 & 17.2 \\
\hline Natural Gas & 48.0 & 15.3 \\
\hline
\end{tabular}

The Tier 2 method was used in estimating the carbon footprint resulting from the use of electricity at the facility, as the emission factors are country specific (Eq. 5).

$$
\begin{aligned}
& \mathrm{CO}_{2} \text { Emission }\left[\text { ton } \mathrm{CO}_{2}\right]=\text { Electricity Consumption }[\mathrm{kW}] \mathrm{x} \\
& \mathrm{CEF}[\mathrm{kg} / \mathrm{kW}]
\end{aligned}
$$

Estimated emissions from road transport are based on two independent data sets as fuel consumption and vehicle kilometers [26].

\section{RESULTS}

\subsection{Carbon Footprint Estimation for Transportation}

In the transportation-related carbon footprint estimation, the collection of wastes from producers, worker service, transportation of wastes within the facility, transportation of products purified from contaminated wastes to rolling mills and other industrial facilities were considered.
Vehicles with a waste transportation license that travel between the facility and the waste producers twice a day have an important share in the carbon footprint of the facility by consuming fuel. There are 6 vehicles in total, including one authority vehicle, one worker service ring vehicle, three waste transport vehicles and one forklift. Only diesel fuel is used in vehicles. Based on the distance traveled by the vehicles belonging to the facility, the total amount of fuel consumed was calculated. The distance traveled by the vehicles was defined as the distance between the facility and target points (worker settlements, waste producers) and the average distance was determined using google map. For the service vehicle, the distance between facility site and the point of departure was measured as $40 \mathrm{~km}$ in average and $80 \mathrm{~km}$ in total for round trip using the Google Map distance calculation tool. The trip value of $80 \mathrm{~km}$ is valid for the authority vehicle. The distance between the facility site and Kayseri Organized Industrial Zone, where waste is collected with 3 separate vehicles twice a day, is $30 \mathrm{~km}$. The location of facility site, worker settlements and waste producers were shown in Figure 1 . The total capacity of 3 vehicles is 22 tons. The distance covered by 3 vehicles in a day has been calculated as $360 \mathrm{~km}$. In addition, assuming that the forklift travels 10 $\mathrm{km}$ per day, it has been taken into account that 6 vehicles travel $530 \mathrm{~km}$ in a day. The facility works 6 days a week, an average of 300 days a year (12 days are considered public holidays) in one shift. In total, 6 vehicles in the facility travel $530 \mathrm{~km}$ per day and $159000 \mathrm{~km}$ per year. Waste is collected from Yozgat and Gaziantep once a month and a distance of $980 \mathrm{~km}$ in a month and a total of $11,760 \mathrm{~km}$ per year is covered. A total distance of 170760 $\mathrm{km} /$ year is covered for the waste collected from the neighboring regions and surrounding provinces. Considering the brand, model and other characteristics of the vehicles in the facility, if it is assumed that $24 \mathrm{~L}$ of fuel is consumed per $100 \mathrm{~km}$ on average, $40982.4 \mathrm{~L}$ diesel fuel is consumed if 6 vehicles travel a total of $170760 \mathrm{~km}$ per year. In order to calculate the energy consumption, the specific weight of diesel fuel $(0.7798 \mathrm{~kg} / \mathrm{L})$ was used to find the value in tons of fuel [27].

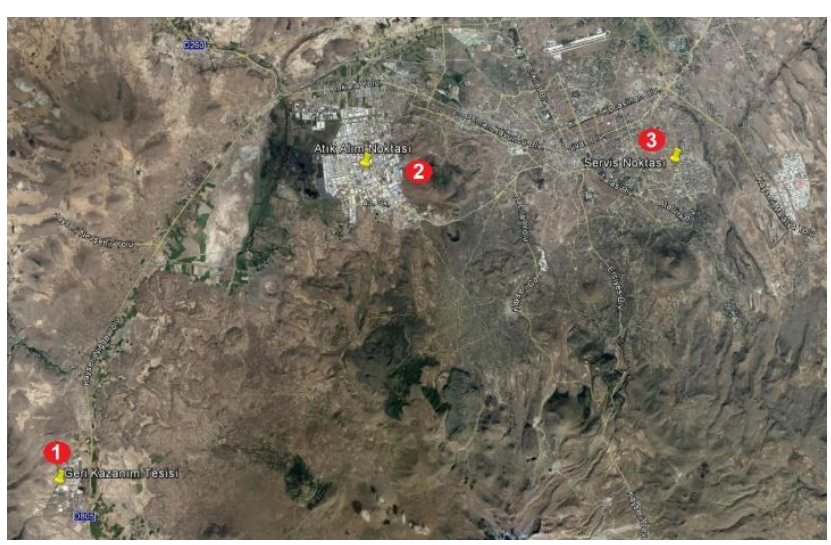

Figure 1. The location of Waste Recovery Facility (1), waste collection points (2) and settlements of workers (3).

The amount of fuel (ton) $=40982.4 \mathrm{~L} * 0.7798 \mathrm{~kg} / \mathrm{L} * 10^{-3}=$ 31.96 ton 
The conversion factor and carbon emission factor are selected from Table 1 as 43.3 and 20.2 used to calculate energy consumption by Eq. 1, respectively.

$$
\begin{aligned}
& \mathrm{EC}[\mathrm{tJ}]=31.96 \mathrm{ton} * 10^{-3} * 43.3 \mathrm{tJ} / \mathrm{kt}=1.38 \mathrm{tJ} \\
& \mathrm{CC}[\mathrm{Gg} \mathrm{C}]=1.38 \mathrm{tJ} * 10^{-3} * 20.2 \mathrm{tC} / \mathrm{tJ}=0.028 \mathrm{Gg} \mathrm{C}
\end{aligned}
$$

In the next step, to find the amount of oxidized carbon, carbon content was converted into carbon dioxide using the percentage of oxidation of fuels. Petroleum-derived liquid fuels are oxidized at a rate of $99 \%$ (UN, 1994).

$$
\begin{aligned}
& \mathrm{CE}[\mathrm{Gg} \mathrm{C}]=0.028 \mathrm{Gg} \mathrm{C} * 0.99=0.0277 \mathrm{Gg} \mathrm{C} \\
& \mathrm{CO}_{2} \text { Emission }[\mathrm{Gg} \mathrm{CO}]=0.0277 \times \frac{\mathbf{4 4}}{\mathbf{1 2}}=0.102 \mathrm{Gg} \mathrm{CO}_{2} \\
& \mathrm{CO}_{2} \text { Emission }\left[\text { ton } \mathrm{CO}_{2}\right]=0.102 \mathrm{Gg} \mathrm{CO}_{2} * 10^{6} \cong \mathbf{1 0 2 0 0 0} \\
& \text { t CO} 2
\end{aligned}
$$

The carbon footprint arising from transportation has been calculated in 3 categories: in-plant, waste collection and worker service ring. The majority of estimated carbon footprint is because of waste collection from producers than worker service ring and in-plant activities. The ratios of carbon footprint estimation for three categories are given in Figure 2.

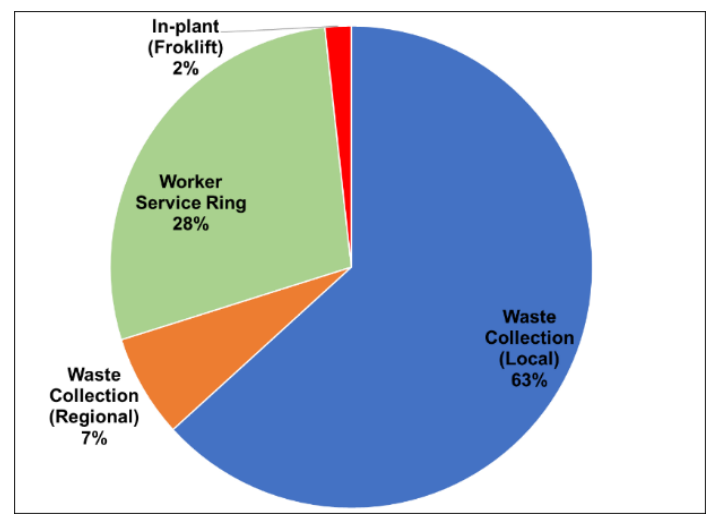

Figure 2. The ratios of carbon footprint estimation for waste collection, worker service ring and in-plant activities.

\subsection{Carbon Footprint Estimation for Heating}

The facility is used for natural gas steam boiler, treatment plant and administrative building (cooking, heating, emergency shower and hot water supply). The amount of natural gas consumption was obtained from the values stated in the monthly invoices. Since natural gas is among the fuel types due to its structure, the carbon footprint resulting from heating was calculated similar to transportation according to Tier 1 method, one of the IPCC methodologies.

According to the invoice information received from the facility, an average of $1200 \mathrm{~m}^{3}$ per month and $14400 \mathrm{~m}^{3}$ per year of natural gas is consumed. The specific gravity of natural gas is $0.798 \mathrm{~kg} / \mathrm{m}^{3}$ [27]. The weight of $14400 \mathrm{~m} 3$ natural gas is approximately 11.491 tons. Using the net calorific value of natural gas and conversion factor given in Table 1 and the amount of fuel consumed, the energy consumption amount was determined with the help of Equation 1.

$$
\begin{aligned}
& \mathrm{EC}(\mathrm{TJ})=11.491 * 10-3 \mathrm{kt} * 48.0 \mathrm{tJ} / \mathrm{kt}=0.55 \mathrm{tJ} \\
& \mathrm{CC}(\mathrm{tC})=0.55 \mathrm{tJ} * 15.3 \mathrm{tC} / \mathrm{tJ}=8.415 \mathrm{tC}
\end{aligned}
$$

In the next step, gas was converted into carbon emission using the percentage of oxidation of fuels in order to find the amount of oxidized carbon. The oxidation percentage of gaseous fuels is 0.995 . Then, carbon dioxide emission is calculated using Equation 4.

$$
\begin{aligned}
& \mathrm{CE}(\mathrm{tC})=8.415 \mathrm{tC} * 0.995=8.37 \mathrm{tC} \\
& \mathrm{CO}_{2}\left(\mathrm{tCO}_{2}\right)=8.37 \mathrm{tC} * \frac{\mathbf{4 4}}{\mathbf{1 2}}=30.7 \mathrm{tCO}_{2} \cong \mathbf{3 0 7 0 0} \mathbf{t} \mathbf{C O}_{2}
\end{aligned}
$$

\subsection{Carbon Footprint Estimation for Electricity Consumption}

The facility is used in the electric press area, washing area, machine park and administrative building. It is used extensively in the field of washing and pressing. The machines used for in the facility including scale, spiral, hydraulic crane, press, polyp, chemical treatment, washing, transformer, treatment plant and crushing machines provide their energy from the electricity network. According to the invoice information provided by the facility, the electricity consumption value is on average $1932 \mathrm{~kW}$ per month and $23184 \mathrm{~kW}$ per year. The emission factor used in the calculations is taken from the International Energy Agency (IEA) report. This report contains emission factors determined specifically for countries. Due to countryspecific emission factors, Tier 2 method was used to determine the carbon footprint resulting from electricity consumption. The emission factor values were determined for Turkey $0.478 \mathrm{~kg} \mathrm{CO} / \mathrm{kW}$ reported by Turkish Statistical Institute [27].

In the first stage, the emission factor given was multiplied by the electricity consumption value received from the facility in order to find the amount of carbon dioxide generated in ton value.

$\mathrm{CO}_{2}$ Emission [ton $\mathrm{CO}_{2}$ ] $=23184 \mathrm{~kW} * 0.478 \mathrm{~kg} \mathrm{CO} / \mathrm{kW}$ $* 10-3 \mathrm{t} / \mathrm{kg} \cong 11 \mathrm{t} \mathrm{CO}_{2}$

The amounts of carbon footprint for activities and their rates in Waste Recovery Facility are summarized in Table 2 .

Table 2. The amounts of carbon footprint for activities and their rates in Waste Recovery Facility

\begin{tabular}{|l|c|c|}
\hline Activity & $\begin{array}{c}\text { The amount of } \\
\text { Carbon Footprint } \\
\text { (t CO2 eq.) }\end{array}$ & $\begin{array}{c}\text { The activity } \\
\text { ratio (\%) }\end{array}$ \\
\hline Transportation & 102000 & 76.8 \\
\hline Heating & 30700 & 23.1 \\
\hline Electricity & 11 & $<1$ \\
\hline Total & $\mathbf{1 3 2 7 1 1}$ & $\mathbf{1 0 0}$ \\
\hline
\end{tabular}

\section{CONCLUSIONS}

In this study, the carbon footprint caused by the activities of a Waste Recovery/Recycling Facility has been evaluated. The carbon footprint of the facility has been determined under 3 main headings, which are transportation, heating and electricity usage. The largest share in the carbon footprint created by the facility comes 
from transportation with $76.8 \%$. The second largest share is the heating-related carbon footprint with $23.1 \%$. The carbon footprint resulting from the use of electricity in the facility has the lowest share $(>0.1 \%)$. In calculating the carbon footprint due to electrical use, the emission factor determined by the International Energy Agency to Turkey were found to be used annually 11 tons of $\mathrm{CO}_{2}$. The total carbon footprint amount caused by the activities of the facility has been determined as 132711 tons of $\mathrm{CO}_{2}$. Published by TurkStat in 2017 greenhouse gas emissions reported in Turkey's total carbon footprint amounts it is expressed in 475.1 million tons of $\mathrm{CO}_{2}$. to about 3,600 times. The potential carbon footprint in Turkey is equal to about 3600 times of the amount of the carbon footprint caused by the facility.

In order to reduce carbon footprint of transportation, waste collection can be optimized. In the optimization of transportation, the frequency of collection waste from facilities can be reduced by collecting waste with the larger vehicles. On the other hand, the Recover/Recycle Facility can be moved far closer to Kayseri Organized Industrial Zone where the waste is collected; therefore, the distance between them will be shorter and the fuel consumption of the vehicles will decrease. Among other sources, the carbon footprint resulting from the use of electricity is negligible.

\section{REFERENCES}

[1] E.A. Page, Distributing the burdens of climate change, Environmental Politics, Vol. 17, pp. 556-575, 2008.

[2] S. Agrawala, Context and early origins of the Intergovernmental Panel on Climate Change, Climatic Change, Vol. 39, pp. 605-620, 1998.

[3] J.W. Zillman, A history of climate activities, World Meteorological Organization (WMO) Bulletin, Vol. 58, pp. 141, 2009.

[4] G. Civelekoğlu and Y. Bıyık, Isparta İlinde Karayolu Kaynaklı Karbon Ayak İzinin Hesaplanması. Bilge International Journal of Science and Technology Research, Vol. 4, pp. 78-87, 2020.

[5] A.V. Morgan, The Changing Atmosphere Conference, Geoscience Canada, Vol. 15, pp. 287-290, 1988.

[6] T. Atabey 2013. Karbon Ayak İzinin Hesaplanması: Diyarbakır Örneği. Fırat Üniversitesi, Fen Bilimleri Enstitüsü, Yüksek Lisans Tezi, 84s, Elazığ.

[7] United Nations (UN) 1994. United Nations Framework for Climate Change Convention, Earth Summit, June 20, 1992, New York.

[8] E. Karakaya, Küresel Isınma ve Kyoto Protokolü: İklim Değişikliğinin Bilimsel, Ekonomik ve Politik Analizi. Bağlam Yayıncılık, 2008.

[9] A. Öztürk, U. Demirci and M. Türker, İklim değişikliğgi ile mücadelede karbon piyasaları ve Türkiye için bir değerlendirme, Kahramanmaraş Sütçü Imam Üniversitesi Doğa Bilimleri Dergisi, Özel Sayı, pp 306-312, 2012.

[10] M. Uzunçakmak 2014. Ulaşım Modlarından Kaynaklanan Sera Gazı Emisyonları Ve iklim Değişikliği Üzerindeki, Ulaştırma ve Haberleşme Uzmanlığı Tezi, 171s, Ankara.
[11] M. Türkeş, U. Sümer and G. Çetiner, Kyoto Protokolü esneklik mekanizmalar1, Tesisat Dergisi, Vol. 52, pp. 84-100, 2000.

[12] D. Pandey, M. Agrawal and J.S. Pandey, Carbon footprint: current methods of estimation, Environmental Monitoring and Assessment, Vol. 178, pp. 135-160, 2011.

[13] C. Goodall, Could reducing your carbon footprint be both fun and profitable, Nature, Vol. 4, pp. 58-59, 2007.

[14] M. Wackernagel and W. Rees, Our ecological footprint: reducing human impact on the earth (Vol. 9). New society publishers, 1996.

[15] T. Wiedmann and J. Minx 2007. ISAUK Research Report 07-01, A definition of carbon footprint. Durham, United Kingdom: ISAUK Research and Consulting.

[16] T. Wiedmann and J. Minx, A definition of "carbon footprint", Ecological Economics Research Trends, Vol. 1, pp. 1-11. 2008.

[17] A. Ghozali, and N. Hasanah, Optimization of settlement land use through carbon footprint approach in The North Balikpapan, IOP Conference Series: Earth and Environmental Science, Vol. 340, p. 012001, 2019.

[18] A.J. East, What is a carbon footprint? An overview of definitions and methodologies, Proc. Vegetable Industry Carbon Footprint Scoping StudyDiscussion Papers and Workshop, 26 September 2008, Horticulture Australia Limited.

[19] M.Finkbeiner, Carbon footprinting-Opportunities and threats, International journal of Life Cycle Assessment, Vol. 14, pp. 91-94, 2009.

[20] G.P. Peters, Carbon footprints and embodied carbon at multiple scales, Current Opinion in Environmental Sustainability, Vol. 2, pp. 245-250, 2010.

[21] J. Patel, Green sky thinking, Environment Business, pp. 122, 32, 2006.

[22] D. Caro, Carbon footprint, Reference Module in Earth Systems and Environmental Sciences Encyclopedia of Ecology (Second Edition), 4, 252-257, 2019.

[23] G. Jonker and J. Harmsen, Engineering for Sustainability: A Practical Guide for Sustainable Design; Elsevier, Amsterdam, The Netherlands, 2012.

[24] S. Mehrotra, B. Lefevre, R. Zimmerman, H. Gerçek, K. Jacob and S. Srinivasan, Climate change and urban transportation systems, Climate Change and Cities First Assessment Report of the Urban Climate Change Research Network (pp. 145-177). Cambridge University Press, 2011.

[25] M. Özen and H. Tüydeş-Yaman, Türkiye'de Şehirlerarası Yük Trafiği $\mathrm{CO}_{2} \quad$ Emisyonlarının Tahmini, Süleyman Demirel Üniversitesi Fen bilimleri Enstitüsü Dergisi, Vol. 17, pp. 56, 2013.

[26] Intergovernmental Panel on Climate Change (IPCC) 2006. IPCC Guidelines for National Gas Inventories, Volume 2, Chapter 2. Intergovernmental Panel on Climate Change, Paris.

[27] Turkey Statistics Institution (TSI) 2017. Greenhouse gas emissions inventory, Water and Wastewater Sector Statistics, No. 24588, Ankara. 